\title{
Instrument for Testing Innovation on the Sustainable Growth of Manufacturing SMEs in Nigeria: A Pilot Study
}

\author{
Danjuma T. Nimfa ${ }^{1}$, Ahmad S. A. Latiff ${ }^{1} \&$ Sazali A. Wahab ${ }^{1}$ \\ ${ }^{1}$ Putra Business School, Universiti Putra Malaysia, Malaysia \\ Correspondence: Danjuma T. Nimfa, Putra Business School, Malaysia. E-mail: danjuma.phd_mgt18 @ \\ grad.putrabs.edu.my
}

Received: March 11, 2020; Accepted: June 15, 2020; Published: June 16, 2020

\begin{abstract}
This paper is based on a pilot study which was conducted to test innovation on the sustainable growth of SMEs by focusing on the methodological viewpoints. The objective of the pilot study was to assess the viability, length of time, cost, and adverse effects of innovation on the sustainable growth of SMEs in Nigeria so as to enhance the design of the questionnaire before its full implementation. A review of the research instrument was performed by four multi-disciplinary academics who specialised in management, accounting, and strategic management, respectively. The aim was to ensure consistency in the questionnaire so that respondents would have no trouble completing them. The statistical package for social sciences (SPSS) Version 23 was used to assist in the exploratory factor analysis (EFA) which tests for reliability and the Cronbach alpha values were used to examine the content and face validity of the instrument. All the constructs and items used in the model were adapted from previous literature. The sample size used for the study comprised 100 respondents recruited from the SMEs operating in Nigeria. The findings showed that all the constructs in the model carried a high Cronbach alpha value of above 0.7 . Therefore, all items used in the instrument were retained. This study is expected to contribute to the literature on methodological multivariate studies, the quantitative approach research on innovation, and the sustainable growth of SMEs.
\end{abstract}

Keywords: pilot study, innovation, sustainable growth of SMEs, quantitative approach, methodological viewpoint

\section{Introduction}

Upon completion, the final draft of the survey questionnaire was despatched to the four experts who academics were specialising in management and strategic management so that the instrument can be evaluated for further review. This was termed as pre-testing, an important stage for ensuring that there was no ambiguity in the questions designed so that the information required can be extracted as intended (Sekaran, 2003; Memon, Ting, Ramayah, Chuah, \& Cheah, 2017). A pre-test usually uses a small-scale trial of a particular research component which may involve written or oral feedback. In the context of the pre-test done in this study, no substantial problem was detected with the questionnaire wordings and design. Nonetheless, some minor adjustments following the experts' recommendations were made prior to the pilot study (Saunders, Lewis \& Thornhill 2012). The pilot study is a preliminary study. It focuses on the entire research procedure, but only a small sample is used. This pilot study adopted the exploratory factor analysis (EFA) (Pearson \& Mundform, 2010), with the aid of the SPSS Version 23, to analyse the accuracy of the findings. The Cronbach alpha was used to assess the content and face validity of the variables and measurement items used. The exploratory factor analysis (EFA) is a statistical method that reduces a large number of observed variables into a small number of "factors/ components" which reflect the common clusters (Hadi, Abdullah \& Sentosa, 2016; Bento, Gaultney \& Dahlquist, 2020).The exploratory factor analysis (EFA) is thus, a valuable tool for analysing the relationship between the measured constructs.

The sample size used for this pilot study comprised 100 respondents. The decision was based on the recommendation of past studies (Memon et al., 2017). For instance, Cooper and Schindler (2011) mentioned that a target sample size of between 25-100 persons is enough for conducting a pilot study involving a survey. This was confirmed by Connelly (2008) who maintained that 10 percent of the sample estimated for the main study should serve as the sample size for the pilot study. Cooper and Schindler (2011) also maintained that the target sample size could also be based on the kind of examination conducted at the phase of the evaluation while Hill (1998), and Isaac and Michael (1995) noted that the range of between 10-30 individuals is adequate for a pilot test. 
Thus, this study administered the survey questionnaire on 100 target respondents so as to ensure that the outcome derived from the exploratory factor analysis would be consistent with prior studies (Hoque, Awang, Jusoff, Salleh \& Muda, 2017; Jung \& Lee, 2011; Gorsuch, 1983; Hair, Black, Babin \& Anderson, 2010; Sang, Mail, Karim, Ulum, Mifli \& Lajuni, 2017; Kline, 1994). The 100 respondents were contacts who were attached to 52 manufacturing SMEs in the North Central Geopolitical Zone of Nigeria The survey attempted to gather their demographic information as well as some background information about their respective enterprise or firms from the North Central Geopolitical Zone of Nigeria. The 100 respondents were approach using simple random sampling, via mailed survey. Their input would help to shed some light on how the main study could be conducted (Kelley, Clark, Brown \& Sitzia, 2003).

\section{Frequency Analysis}

The demographic analysis derived from the pilot-study was categorised in two ways: the respondents' profile and their enterprises' background information such as present business status, sub-sector of the enterprise, number of full-time employees hired, nature of enterprise's business unit/legal status, and basic enterprise assets (excluding land and buildings). The demographics of the respondents were described in six different areas: gender, age, highest qualification, responsibilities, years of services or working experience, and location/area where data was collected. The details of the frequency analysis are presented in the tables provided below.

\subsection{Demographics of the Enterprises (Manufacturing SMEs)}

Details of the enterprises comprised of several components as illustrate in Table 1 below. The details are presented in terms of frequency analysis.

Table 1. How would you describe the present business status of your manufacturing enterprise?

\begin{tabular}{|c|c|c|c|c|c|}
\hline & & Frequency & Percent & Valid Percent & Cumulative Percent \\
\hline \multirow{4}{*}{$\frac{\pi}{\pi}$} & Novel concept that has never existed & 15 & 15.0 & 15.0 & 15.0 \\
\hline & $\begin{array}{l}\text { Established from an existing concept of } \\
\text { manufacturing enterprise in Nigeria }\end{array}$ & $\mathrm{f}_{69}$ & 69.0 & 69.0 & 84.0 \\
\hline & $\begin{array}{l}\text { Established from existing concept of } \\
\text { manufacturing enterprise outside Nigeria }\end{array}$ & $f_{16}$ & 16.0 & 16.0 & 100.0 \\
\hline & Total & 100 & 100.0 & 100.0 & \\
\hline
\end{tabular}

Table 1 shows three general outcomes with majority describing the business status of their enterprises as 'established from an existing concept of manufacturing in Nigeria'. Almost an equal amount of the respondents stated that the business status of their enterprises were 'established from existing concept of manufacturing outside of Nigeria' (16\%), and 'novel concept that had never existed' $(15 \%)$. This result revealed that majority of the respondents were attached to enterprises that had been established from the existing concept of manufacturing enterprises in Nigeria.

The survey noted in this pilot study also aimed to measure the length of time the respondents' enterprises had been operating in Nigeria. Table 2 below illustrates the results.

Table 2. How long has your manufacturing enterprise been incorporated in Nigeria?

\begin{tabular}{|c|c|c|c|c|c|}
\hline & & Frequency & Percent & Valid Percent & Cumulative Percen \\
\hline \multirow{8}{*}{$\frac{\pi}{\pi}$} & $1-5$ years & 5 & 5.0 & 5.0 & 5.0 \\
\hline & $6-10$ years & 21 & 21.0 & 21.0 & 26.0 \\
\hline & $11-15$ years & 22 & 22.0 & 22.0 & 48.0 \\
\hline & $16-20$ years & 29 & 29.0 & 29.0 & 77.0 \\
\hline & $21-25$ years & 10 & 10.0 & 10.0 & 87.0 \\
\hline & $26-30$ years & 4 & 4.0 & 4.0 & 91.0 \\
\hline & Above 31 years & 9 & 9.0 & 9.0 & 100.0 \\
\hline & Total & 100 & 100.0 & 100.0 & \\
\hline
\end{tabular}

The information displayed in the table shows that $5 \%$ of the respondents' enterprises had been established in Nigeria from $1-5$ years, $21 \%$ of the enterprises had been established from 6 to 10 years, $22 \%$ of the enterprises had 
been established from 11-15 years, $29 \%$ of the enterprises had been established from $16-20$ years, $10 \%$ of the enterprises had been established from $21-25$ years, $4 \%$ of the enterprises had been established from $26-30$ years, and $9 \%$ of the enterprises had been established more than 31 years. This result showed that majority of the SMEs are well established, from 16-20 years.

The table below outlines the respondents' enterprises in terms of the manufacturing sector.

Table 3. Which manufacturing sub-sector does your enterprise belong to?

\begin{tabular}{lrrrr}
\hline & Frequency & Percent & Valid Percent & Cumulative Percent \\
\hline Food \& beverages SMEs & 15 & 15.0 & 15.0 & 15.0 \\
Cement manufacturing SMEs & 12 & 12.0 & 12.0 & 27.0 \\
Electrical wire and cables products SMEs & 11 & 11.0 & 11.0 & 38.0 \\
Textile and fabrics products SMEs & 17 & 17.0 & 17.0 & 55.0 \\
Taints and building materials SMEs & 15 & 15.0 & 15.0 & 70.0 \\
Paither works products SMEs & 8 & 8.0 & 8.0 & 78.0 \\
Leather & 8 & 8.0 & 8.0 & 86.0 \\
Consumers goods (all consumables) SMEs & 14 & 14.0 & 14.0 & 100.0 \\
Fabricated metal products SMEs & 100 & 100.0 & 100.0 & \\
Total & & & & \\
\hline
\end{tabular}

From the information provided, it appears that majority of the respondents (17/100) were from the Textile \& Fabrics sector, $15 \%$ were from the Food \& Beverages industry, and 15\% were from the Paints \& Building Materials industry. The lowest of the participation came from the Leather Work Products and Consumer Goods industry.

Table 4 below highlights the size of the respondents' enterprises in terms of employees hired.

Table 4. How many full time employees you currently hire

\begin{tabular}{lllll}
\hline & Frequency & Percent & Valid Percent & Cumulative Percent \\
\hline Less than 10 employees & 11 & 11.0 & 11.0 & 11.0 \\
10-49 employees & 62 & 62.0 & 62.0 & 73.0 \\
$50-199$ employees & 27 & 27.0 & 27.0 & 100.0 \\
Total & 100 & 100.0 & 100.0 & \\
\hline
\end{tabular}

As noted from the table, about $11 \%$ of the respondents' enterprise had hired less than 10 employees, $62 \%$ of the enterprises hired between 10 to 49 employees, and $27 \%$ of the enterprises hired between 50 to 199 employees. These results suggest that majority of the respondents were in the middle range enterprises which hired between 10-49 employees.

The table below illustrates the business nature of the respondents' enterprises.

Table 5. What is your manufacturing enterprise form of business unit/legal status?

\begin{tabular}{lllll}
\hline & Frequency & Percent & Valid Percent & Cumulative Percent \\
\hline Sole Proprietorship & 19 & 19.0 & 19.0 & 19.0 \\
Partnership & 23 & 23.0 & 23.0 & 42.0 \\
Limited Liability & 15 & 15.0 & 15.0 & 57.0 \\
Private Shareholding & 18 & 18.0 & 18.0 & 75.0 \\
Joint Venture & 17 & 17.0 & 17.0 & 92.0 \\
Franchise & 8 & 8.0 & 8.0 & 100.0 \\
Total & 100 & 100.0 & 100.0 & \\
\hline
\end{tabular}

Table 5 indicates that majority or $23 \%$ of the respondents' enterprise was of the partnership type, followed by Sole Proprietorship (19\%), Private Shareholding (18\%), Joint Venture (17\%), Limited Liability (15\%), and the least was the Franchise Type (8\%). This outcome shows that majority of the respondents' enterprise belonged to the partnership form of business unit/legal status. 
Table 6. What is your manufacturing Assets based (Excluding Land and Buildings)?

\begin{tabular}{|c|c|c|c|c|c|}
\hline & & Frequency & Percent & Valid Percent & Cumulative Percent \\
\hline \multirow{4}{*}{$\frac{\sqrt[7]{\pi}}{\overbrace{}^{\frac{\pi}{\pi}}}$} & Less than 5 & 11 & 11.0 & 11.0 & 11.0 \\
\hline & 5 to less than 50 & 65 & 65.0 & 65.0 & 76.0 \\
\hline & 50 to less than 500 & 24 & 24.0 & 24.0 & 100.0 \\
\hline & Total & 100 & 100.0 & 100.0 & \\
\hline
\end{tabular}

From the table, it can be seen that $11 \%$ of the respondents' enterprise had assets of below five million naira, $65 \%$ of the respondents' enterprise had assets of between five million naira to below 50 million naira, and $24 \%$ of the respondents' enterprise had assets of between 50 million naira to below 500 million naira. The findings suggest that majority of the enterprises were in the medium range of between five to below 50 million naira.

\subsection{Demographics of the Respondents}

The demographics of the respondents were also noted in the tables below.

Table 7. What is your gender?

\begin{tabular}{|c|c|c|c|c|c|}
\hline & & Frequency & Percent & Valid Percent & Cumulative Percent \\
\hline \multirow{3}{*}{$\frac{\sqrt[\sigma]{7}}{2}$} & Male & 53 & 53.0 & 53.0 & 53.0 \\
\hline & Female & 47 & 47.0 & 47.0 & 100.0 \\
\hline & Total & 100 & 100.0 & 100.0 & \\
\hline
\end{tabular}

Table 7 indicates the gender of the respondents with almost equal number of males (53\%) and females (47\%).

Table 8 . What is your age range?

\begin{tabular}{|c|c|c|c|c|c|}
\hline \multirow{7}{*}{$\overline{\text { Valid }}$} & & Frequency & Percent & Valid Percent & Cumulative Percent \\
\hline & $21-30$ years old & 13 & 13.0 & 13.0 & 13.0 \\
\hline & $31-40$ years old & 27 & 27.0 & 27.0 & 40.0 \\
\hline & 41 - 50 years old & 23 & 23.0 & 23.0 & 63.0 \\
\hline & $51-60$ years old & 30 & 30.0 & 30.0 & 93.0 \\
\hline & 61 years old and above & 7 & 7.0 & 7.0 & 100.0 \\
\hline & Total & 100 & 100.0 & 100.0 & \\
\hline
\end{tabular}

Table 8 stresses on the age of the respondents with majority or $30 \%$ of them being in the 51 to 60 years old range, and a minority in the above 61 years old range. Overall, it can be said that most of the respondents were matured or experienced, with an overall of $87 \%$ of them being above 31 years of age, and only $13 \%$ between 21 to 30 years of age.

Table 9. Your highest qualification

\begin{tabular}{lrrrr}
\hline & Frequency & Percent Valid Percent & Cumulative Percent \\
\hline Doctor of Philosophy/ Doctor of Business & 15 & 15.0 & 15.0 & 15.0 \\
Administration & & & & \\
Master of Philosophy/ Master of Science/Master of & 17 & 17.0 & 17.0 & 32.0 \\
Business Admin & 17 & 17.0 & 17.0 & 49.0 \\
Bachelor Degree/Higher National Diploma & 14 & 14.0 & 14.0 & 63.0 \\
B. & 19 & 19.0 & 19.0 & 82.0 \\
Diploma/ Nigerian Certificate of Education & 11 & 11.0 & 11.0 & 93.0 \\
Professional Certificate/Training & 7 & 7.0 & 7.0 & 100.0 \\
Secondary School Certificate Examination & 100 & 100.0 & 100.0 & \\
First School Leaving Certificate & & & & \\
Total & &
\end{tabular}


Table 9 highlights the respondents' academic qualifications which seemed to be diverse, ranging from doctoral degrees to first school leaving certifications. Around 15\% held a Doctor of Philosophy/ Doctor of Business Administration degree, $17 \%$ held a Masters of Philosophy/ Masters of Science/Master of Business Administration, $7 \%$ held a Bachelor's degree/Higher National Diploma, 14\% held their Diploma/Nigerian Certificate of Education, $19 \%$ had professional certificate/training, and $7 \%$ had first school leaving certificates. Based on this, it is deduced that majority of the respondents were fairly well educated.

Table 10. Your responsibilities in the manufacturing enterprise

\begin{tabular}{lrrrr}
\hline & Frequency & Percent & Valid Percent & Cumulative Percent \\
\hline Chief Executive Officer (CEO)/Managing & 42 & 42.0 & 42.0 & 42.0 \\
Director (MD) & 30 & 30.0 & 30.0 & 72.0 \\
Founder/Owner-manager & 20 & 20.0 & 20.0 & 92.0 \\
Fon Director/General Manager/Unit & 8 & 8.0 & 8.0 & 100.0 \\
Head/Departmental head/Principal Manager & 100 & 100.0 & 100.0 & \\
Supervisor/Manager & & & & \\
Total &
\end{tabular}

Table 10 shows the work designation of the respondents involved. Nearly half or $42 \%$ of the respondents were the Chief Executive Officers (CEO)/Managing Directors (MD), about 30\% were the founder/owner-managers, 20\% of the respondents were Directors/General Managers/Unit Heads/Departmental Heads/Principal Managers and 8\% were Supervisors/Managers. The result revealed that majority of the respondents examined in this pilot study comprised the CEOs or Managing Directors.

Table 11. How many years have you served in this manufacturing enterprise?

\begin{tabular}{lrrrr}
\hline & Frequency & Percent & Valid Percent & Cumulative Percent \\
\hline Less than 1 year & 5 & 5.0 & 5.0 & 5.0 \\
1 -5 years & 19 & 19.0 & 19.0 & 24.0 \\
6-10 years & 29 & 29.0 & 29.0 & 53.0 \\
11-15 years & 23 & 23.0 & 23.0 & 76.0 \\
16-20 years & 13 & 13.0 & 13.0 & 89.0 \\
21- years and above & 11 & 11.0 & 11.0 & 100.0 \\
Total & 100 & 100.0 & 100.0 & \\
\hline
\end{tabular}

The table above displays the respondents' length of time serving in their respective work responsibilities. It appears that $5 \%$ of the respondents had less than a year's working experience, $19 \%$ of the respondents had between $1-5$ years working experience, $29 \%$ of the respondents had 6-10 years working experience, $23 \%$ of the respondents had $11-15$ years working experience, $13 \%$ of the respondents had $16-20$ years working experience, and $11 \%$ of the respondents had 21 years and above in working experience. The result showed that more of the respondents were in the 6-10 years working experience.

Table 12. Location (Area)

\begin{tabular}{|c|c|c|c|c|c|}
\hline & & Frequency & Percent & Valid Percent & Cumulative Percent \\
\hline \multirow{8}{*}{$\frac{T}{\pi}$} & Abuja-FCT & 19 & 19.0 & 19.0 & 19.0 \\
\hline & Benue State & 15 & 15.0 & 15.0 & 34.0 \\
\hline & Kogi State & 12 & 12.0 & 12.0 & 46.0 \\
\hline & Kwara State & 14 & 14.0 & 14.0 & 60.0 \\
\hline & Niger State & 16 & 16.0 & 16.0 & 76.0 \\
\hline & Nasarawa State & 13 & 13.0 & 13.0 & 89.0 \\
\hline & Plateau State & 11 & 11.0 & 11.0 & 100.0 \\
\hline & Total & 100 & 100.0 & 100.0 & \\
\hline
\end{tabular}


Table 12 shows that $19 \%$ of the respondents came from Abuja-FCT, $15 \%$ of them came from Benue State, $12 \%$ of them came from Kogi State, $14 \%$ of them were from Kwara State, $16 \%$ of them were from Niger State, $13 \%$ of them came from Nasarawa State, and $11 \%$ of them were from Plateau State. Thus, majority were from the AbujaFCT area.

\section{Findings and Analysis}

The reliability of the questionnaire scale was tested using the Cronbach alpha value. The initial items in each construct included in the questionnaire used in this pilot study is shown in Table 13 below.

Table 13. Initial Items for each Construct used in the Questionnaire

\begin{tabular}{|c|c|c|c|}
\hline Construct & Sub-construct & $\begin{array}{l}\text { No. of } \\
\text { Items }\end{array}$ & Role \\
\hline \multirow{4}{*}{$\begin{array}{l}\text { ORGANISATIONAL CULTURE (OC) } \\
\text { Tang, Kim \& O'Donald, } 2000 .\end{array}$} & Family Orientation /Loyalty & 05 & \multirow[t]{4}{*}{ Independent } \\
\hline & $\begin{array}{l}\text { Open Communication/Consensual } \\
\text { Decision Making }\end{array}$ & 05 & \\
\hline & Team Approach & 05 & \\
\hline & Knowledge of Managers & 05 & \\
\hline \multirow{3}{*}{$\begin{array}{l}\text { STRATEGIC ORIENTATION (SO) } \\
\text { (Cheng \& Huizingh, 2014; Gatignon \& } \\
\text { Xuereb, 1997) }\end{array}$} & Entrepreneurial Orientation (EO) & 05 & \multirow[t]{3}{*}{ Independent } \\
\hline & Market Orientation (MO) & 06 & \\
\hline & Resource Orientation (RO) & 06 & \\
\hline \multicolumn{2}{|l|}{$\begin{array}{l}\text { TECHNOLOGY ORIENTATION (TO) } \\
\text { (Halac, 2015; Gatignon \& Xuereb, 1997)) }\end{array}$} & 08 & Independent \\
\hline STRATEGIC BUSINESS MODEL (SBM) & Business Environment & 06 & \multirow{3}{*}{ Independent } \\
\hline \multirow{2}{*}{ (Pucihar et al., 2019) } & Information Technology & 05 & \\
\hline & Innovation & 05 & \\
\hline \multicolumn{2}{|c|}{$\begin{array}{l}\text { INNOVATION COMPETITIVE ADVANTAGE (ICA) } \\
\text { (Sheng, Chang, Teo \& Lin, 2013; } \\
\text { Paswan \& Wittmann, 2009; Chen, Lin \& Chang, 2009) }\end{array}$} & 06 & Mediator \\
\hline \multirow{2}{*}{\multicolumn{2}{|c|}{$\begin{array}{l}\text { MANAGEMENT SUPPORT (MS) } \\
\text { (Lo, Wang, Wah \& Ramayah 2016; Garrett \& Neubaum, 2013) }\end{array}$}} & 08 & Moderator \\
\hline & & & \\
\hline \multirow{3}{*}{\multicolumn{2}{|c|}{$\begin{array}{l}\text { SUSTAINABLE GROWTH OF MANUFACTURING SMEs (SGMSMEs) } \\
\text { Arora, Kumar \& Thapar (2018); Eggers et al., 2013a, 2013b; Al Ansari, } 2014 . \\
\text { Total }\end{array}$}} & 06 & Dependent \\
\hline & & & \\
\hline & & 81 & \\
\hline
\end{tabular}

The information shown above indicates a total of 81 items used in 14 constructs. To test the reliability of the constructs, the reliability analysis for each of the constructs were assessed, and their Cronbach alpha values were calculated. The results of the Cronbach alpha values are presented below.

\subsection{Family Orientation/Loyalty}

Table 14. Reliability Statistics

\begin{tabular}{lr}
\hline Cronbach's Alpha & N of Items \\
\hline .780 & 5 \\
\hline
\end{tabular}

Table 15. Item-Total Statistics

\begin{tabular}{lrrrr}
\hline & $\begin{array}{r}\text { Scale Mean if Item } \\
\text { Deleted }\end{array}$ & $\begin{array}{r}\text { Scale Variance if Item } \\
\text { Deleted }\end{array}$ & $\begin{array}{r}\text { Corrected Item-Total } \\
\text { Correlation }\end{array}$ & $\begin{array}{r}\text { Cronbach's Alpha if } \\
\text { Item Deleted }\end{array}$ \\
\hline FO_L1 & 12.53 & 11.302 & .589 & .727 \\
FO_L2 & 12.54 & 13.463 & .418 & .780 \\
FO_L3 & 12.53 & 12.534 & .541 & .744 \\
FO_L4 & 12.85 & 11.321 & .599 & .723 \\
FO_L5 & 12.55 & 11.563 & .628 & .714 \\
\hline
\end{tabular}


The construct reliability for the five items used to assess the respondents' family orientation or loyalty was noted to be at the alpha value of 0.780 which was above the threshold of 0.7 , hence the constructs were considered to be at the acceptable level. As a result, there was no need to delete any item.

\subsection{Open Communication/Consensual Decision-Making}

Table 16. Reliability Statistics

\begin{tabular}{lr}
\hline Cronbach's Alpha & N of Items \\
\hline .792 & 5 \\
\hline
\end{tabular}

Table 17. Item-Total Statistics

\begin{tabular}{lrrrr}
\hline & $\begin{array}{r}\text { Scale Mean if Item } \\
\text { Deleted }\end{array}$ & $\begin{array}{r}\text { Scale Variance if Item } \\
\text { Deleted }\end{array}$ & $\begin{array}{r}\text { Corrected Item-Total } \\
\text { Correlation }\end{array}$ & $\begin{array}{r}\text { Cronbach's Alpha if } \\
\text { Item Deleted }\end{array}$ \\
\hline OC_CDM1 & 12.83 & 12.001 & .587 & .753 \\
OC_CDM2 & 12.21 & 13.743 & .568 & .753 \\
OC_CDM3 & 12.53 & 14.211 & .536 & .763 \\
OC_CDM4 & 12.53 & 14.474 & .569 & .755 \\
OC_CDM5 & 12.66 & 13.560 & .620 & .738 \\
\hline
\end{tabular}

The construct reliability for the five items used to assess the respondents' open communication or open decision making carried the alpha value of 0.792 which was above the threshold of 0.7 , hence the constructs were considered to be at the acceptable level. Thus, there was no need to delete any item.

\subsection{Team Approach}

Table 18. Reliability Statistics

\begin{tabular}{lr}
\hline Cronbach's Alpha & N of Items \\
\hline 710 & 5 \\
\hline
\end{tabular}

Table 19. Item-Total Statistics

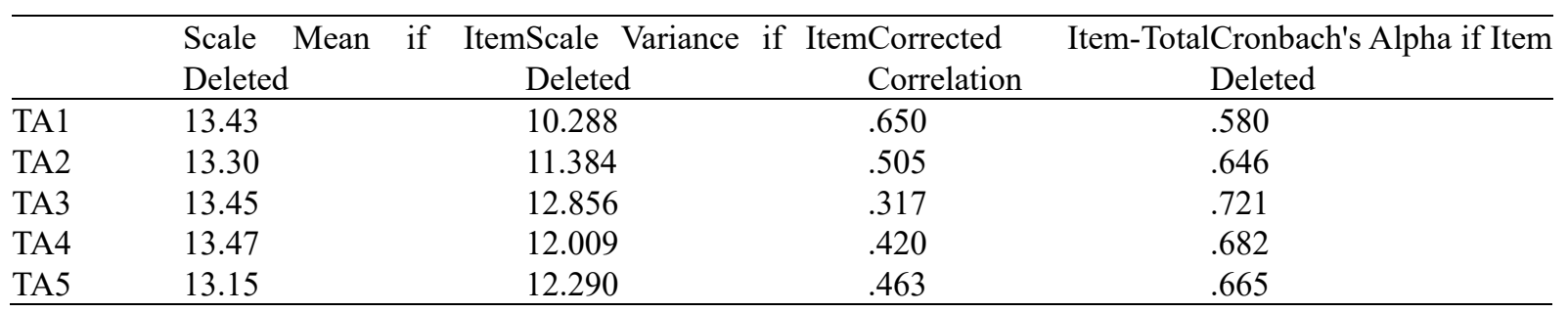

The construct reliability of the five items used to assess the team's approach carried an alpha value of 0.710 which was above the threshold of 0.7 , hence the constructs were considered to be at the acceptable level. In that regard, there was no need to delete any item.

\subsection{Knowledge of Managers}

Table 20. Reliability Statistics

\begin{tabular}{cc}
\hline Cronbach's Alpha & $\mathrm{N}$ of Items \\
\hline .774 & 5 \\
\hline
\end{tabular}


Table 21. Item-Total Statistics

\begin{tabular}{llclc}
\hline & $\begin{array}{l}\text { Scale Mean } \\
\text { Deleted }\end{array}$ & $\begin{array}{c}\text { if } \\
\text { Deleted }\end{array}$ & $\begin{array}{c}\text { ItemScale Variance } \\
\text { if ItemCorrected } \\
\text { Correlation }\end{array}$ & $\begin{array}{c}\text { Item-TotalCronbach's Alpha if Item } \\
\text { Deleted }\end{array}$ \\
\hline KM1 & 12.99 & 14.091 & .433 & .769 \\
KM2 & 12.99 & 12.576 & .594 & .716 \\
KM3 & 13.10 & 12.535 & .589 & .717 \\
KM4 & 13.18 & 12.533 & .612 & .710 \\
KM5 & 13.06 & 13.289 & .506 & .746 \\
\hline
\end{tabular}

The construct reliability of the five items used to measure the managers' knowledge also carried the alpha value of 0.774 which was above the threshold of 0.7 , hence the constructs were also considered to be at the acceptable level. Thus, there was no need to delete any item.

\subsection{Entrepreneurial Orientation (EO)}

Table 22. Reliability Statistics

\begin{tabular}{cc}
\hline Cronbach's Alpha & N of Items \\
\hline .794 & 5 \\
\hline
\end{tabular}

Table 23. Item-Total Statistics

\begin{tabular}{rrrrr}
\hline & $\begin{array}{r}\text { Scale Mean if Item } \\
\text { Deleted }\end{array}$ & $\begin{array}{r}\text { Scale Variance if Item } \\
\text { Deleted }\end{array}$ & $\begin{array}{r}\text { Corrected Item-Total } \\
\text { Correlation }\end{array}$ & $\begin{array}{r}\text { Cronbach's Alpha if Item } \\
\text { Deleted }\end{array}$ \\
\hline EO1 & 12.47 & 16.373 & .652 & .729 \\
EO2 & 12.30 & 17.667 & .542 & .764 \\
EO3 & 12.54 & 16.918 & .547 & .763 \\
EO4 & 12.14 & 16.909 & .553 & .761 \\
EO5 & 12.43 & 17.076 & .575 & .754 \\
\hline
\end{tabular}

The construct reliability of the five items used to assess the respondent's entrepreneurial orientation carried an alpha value of 0.794 which was above the threshold of 0.7 , hence the constructs were considered to be at the acceptable level. In that regard, there was no need to delete any item.

Table 24. Market Orientation (MO)

\begin{tabular}{lr}
\hline Reliability Statistics \\
\hline Cronbach's Alpha & N of Items \\
.756 & 6 \\
\hline
\end{tabular}

Table 26. Item-Total Statistics

\begin{tabular}{rrrrr}
\hline & $\begin{array}{r}\text { Scale Mean if Item } \\
\text { Deleted }\end{array}$ & $\begin{array}{r}\text { Scale Variance if Item } \\
\text { Deleted }\end{array}$ & Corrected Item-TotalCronbach's Alpha if Item \\
Correlation & Deleted \\
\hline MO1 & 16.12 & 18.288 & .529 & .711 \\
MO2 & 16.19 & 18.721 & .510 & .717 \\
MO3 & 19.145 & .456 & .731 \\
MO4 & 15.92 & 18.280 & .518 & .714 \\
MO5 & 16.23 & 19.434 & .431 & .737 \\
MO6 & 16.00 & 18.629 & .530 & .711 \\
\hline
\end{tabular}

The construct reliability for the six items used to assess the respondent's market orientation carried an alpha value of 0.756 which was above the threshold of 0.7 , hence the constructs were considered to be at the acceptable level so there was no need to delete any item. 


\subsection{Resource Orientation (RO)}

Table 27. Reliability Statistics

\begin{tabular}{lr}
\hline Cronbach's Alpha & N of Items \\
\hline .738 & 6 \\
\hline
\end{tabular}

Table 28. Item-Total Statistics

\begin{tabular}{lrrrr}
\hline & $\begin{array}{r}\text { Scale Mean if Item } \\
\text { Deleted }\end{array}$ & $\begin{array}{r}\text { Scale Variance if Item } \\
\text { Deleted }\end{array}$ & $\begin{array}{r}\text { Corrected Item-Total } \\
\text { Correlation }\end{array}$ & $\begin{array}{r}\text { Cronbach's Alpha if Item } \\
\text { Deleted }\end{array}$ \\
\hline RO1 & 16.84 & 16.075 & .585 & .667 \\
RO2 & 16.81 & 16.236 & .553 & .677 \\
RO3 & 16.83 & 18.001 & .410 & .719 \\
RO4 & 16.85 & 16.977 & .516 & .689 \\
RO5 & 16.70 & 18.899 & .330 & .740 \\
RO6 & 16.67 & 17.900 & .453 & .707 \\
\hline
\end{tabular}

The construct reliability of the six items used to assess the respondents' resource orientation carried an alpha value of 0.738 which was above the threshold of 0.7 , hence the constructs were considered to be at the acceptable level. Therefore, there was no need to delete any item.

\subsection{Technology Orientation (TO)}

Table 29. Reliability Statistics

\begin{tabular}{lr}
\hline Cronbach's Alpha & N of Items \\
\hline .756 & 8 \\
\hline
\end{tabular}

Table 30. Item-Total Statistics

\begin{tabular}{lrrrr}
\hline & $\begin{array}{r}\text { Scale Mean if Item } \\
\text { Deleted }\end{array}$ & $\begin{array}{r}\text { Scale Variance if Item } \\
\text { Deleted }\end{array}$ & $\begin{array}{r}\text { Corrected Item-TotalCronbach's Alpha if Item } \\
\text { Correlation }\end{array}$ \\
\hline TO1 & 21.16 & 28.661 & .548 & .711 \\
TO2 & 21.05 & 30.816 & .497 & .723 \\
TO3 & 21.10 & 32.960 & .336 & .749 \\
TO4 & 21.20 & 29.919 & .452 & .730 \\
TO5 & 21.14 & 29.617 & .491 & .723 \\
TO6 & 21.33 & 31.880 & .320 & .755 \\
TO7 & 21.18 & 32.210 & .303 & .758 \\
TO8 & 20.96 & 28.099 & .714 & .684 \\
\hline
\end{tabular}

The construct reliability for the eight items used to assess the respondents' technology orientation carried an alpha value of 0.756 which was above the threshold of 0.7 , hence the constructs were considered to be at the acceptable level. In that regard, there was no need any item.

\subsection{Business Environment}

Table 31. Reliability Statistics

\begin{tabular}{lr}
\hline Cronbach's Alpha & N of Items \\
\hline .781 & 6 \\
\hline
\end{tabular}


Table 32. Item-Total Statistics

\begin{tabular}{rrrrr}
\hline & $\begin{array}{r}\text { Scale Mean if Item } \\
\text { Deleted }\end{array}$ & $\begin{array}{r}\text { Scale Variance if Item } \\
\text { Deleted }\end{array}$ & $\begin{array}{r}\text { Corrected Item-Total } \\
\text { Correlation }\end{array}$ & $\begin{array}{r}\text { Cronbach's Alpha if Item } \\
\text { Deleted }\end{array}$ \\
\hline BE1 & 15.83 & 20.042 & .572 & .737 \\
BE2 & 15.43 & 20.571 & .581 & .736 \\
BE3 & 15.47 & 21.686 & .438 & .770 \\
BE4 & 15.48 & 20.798 & .501 & .755 \\
BE5 & 15.54 & 21.099 & .482 & .760 \\
BE6 & 15.50 & 20.253 & .604 & .730 \\
\hline
\end{tabular}

The construct reliability of six items used to assess the respondents' business environment noted that the alpha value was 0.781 which was above the threshold of 0.7 , hence the constructs were considered to be at the acceptable level. Consequently, there was no need to delete any item.

3.9 Information Technology

Table 33. Reliability Statistics

\begin{tabular}{lr}
\hline Cronbach's Alpha & N of Items \\
\hline .753 & 5 \\
\hline
\end{tabular}

Table 34. Item-Total Statistics

\begin{tabular}{llllc}
\hline & $\begin{array}{l}\text { Scale } \\
\text { Item Deleted }\end{array}$ & $\begin{array}{c}\text { ifScale Variance } \\
\text { Item Deleted }\end{array}$ & $\begin{array}{c}\text { ifCorrected } \\
\text { Total Correlation-Cronbach's Alpha }\end{array}$ & $\begin{array}{c}\text { Item Deleted } \\
\text { if Item }\end{array}$ \\
\hline IT1 & 12.75 & 13.159 & .501 & .715 \\
IT2 & 12.42 & 14.246 & .417 & .742 \\
IT3 & 12.64 & 11.465 & .577 & .687 \\
IT4 & 12.54 & 12.109 & .559 & .694 \\
IT5 & 12.61 & 12.968 & .546 & .700 \\
\hline
\end{tabular}

The construct reliability for five items used to assess the respondents' information technology was noted to have an alpha value of 0.753 which was above the threshold of 0.7 hence the constructs were considered to be at the acceptable level. Thus, there was no need to delete any item.

\section{Innovation}

Table 35. Reliability Statistics

\begin{tabular}{lr}
\hline Cronbach's Alpha & N of Items \\
\hline .830 & 5 \\
\hline
\end{tabular}

Table 36. Item-Total Statistics

\begin{tabular}{lrrrr}
\hline & $\begin{array}{r}\text { Scale Mean if Item } \\
\text { Deleted }\end{array}$ & $\begin{array}{r}\text { Scale Variance if Item } \\
\text { Deleted }\end{array}$ & $\begin{array}{r}\text { Corrected Item-Total } \\
\text { Correlation }\end{array}$ & $\begin{array}{r}\text { Cronbach's Alpha if } \\
\text { Item Deleted }\end{array}$ \\
\hline INNOV1 & 12.82 & 16.634 & .675 & .783 \\
INNOV2 & 12.93 & 16.955 & .636 & .794 \\
INNOV3 & 12.68 & 17.674 & .581 & .809 \\
INNOV4 & 12.87 & 16.579 & .618 & .800 \\
INNOV5 & 12.86 & 17.132 & .631 & .796 \\
\hline
\end{tabular}


The construct reliability for five items used to assess the respondents' reliability was also noted to be 0.830 which was above the threshold of 0.7 hence at the constructs were at the acceptable level. Thus, there was no need to delete any item.

\subsection{Innovation Competitive Advantage (ICA)}

Table 37. Reliability Statistics

\begin{tabular}{ll}
\hline Cronbach's Alpha & N of Items \\
\hline .795 & 6 \\
\hline
\end{tabular}

Table 38. Item-Total Statistics

\begin{tabular}{lrrrr}
\hline & $\begin{array}{r}\text { Scale Mean if Item } \\
\text { Deleted }\end{array}$ & $\begin{array}{r}\text { Scale Variance if Item } \\
\text { Deleted }\end{array}$ & $\begin{array}{r}\text { Corrected Item-TotalCronbach's Alpha if Item } \\
\text { Correlation }\end{array}$ \\
\hline ICA1 & 15.61 & 21.937 & .660 & .738 \\
ICA2 & 15.81 & 22.559 & .508 & .773 \\
ICA3 & 23.165 & .433 & .792 \\
ICA4 & 15.63 & 21.949 & .590 & .753 \\
ICA5 & 15.70 & 23.078 & .513 & .771 \\
ICA6 & 15.55 & 22.250 & .606 & .750 \\
\hline
\end{tabular}

The construct reliability for the six items used to assess the respondents' innovative competition edge also carried an alpha value of 0.795 which was above the threshold of 0.7 hence the constructs were considered to be at an acceptable level. Consequently, there was no need to delete any item.

\subsection{Management Support}

Table 39. Reliability Statistics

\begin{tabular}{lr}
\hline Cronbach's Alpha & N of Items \\
\hline .791 & 8 \\
\hline
\end{tabular}

Table 40. Item-Total Statistics

\begin{tabular}{lrrrr}
\hline & $\begin{array}{r}\text { Scale Mean if Item } \\
\text { Deleted }\end{array}$ & $\begin{array}{r}\text { Scale Variance if Item } \\
\text { Deleted }\end{array}$ & $\begin{array}{r}\text { Corrected Item-TotalCronbach's Alpha if Item } \\
\text { Correlation }\end{array}$ \\
\hline MS1 & 21.57 & 29.783 & .521 & .764 \\
MS2 & 21.46 & 32.049 & .427 & .779 \\
MS3 & 21.65 & 35.260 & .197 & .812 \\
MS4 & 31.172 & .485 & .770 \\
MS5 & 21.80 & 30.937 & .510 & .766 \\
MS6 & 21.65 & 31.078 & .521 & .764 \\
MS7 & 21.35 & 28.818 & .721 & .732 \\
MS8 & 21.49 & 30.084 & .630 & .748 \\
\hline
\end{tabular}

The construct reliability for the eight items used to assess the respondents' management support Carried an alpha value of 0.791 which was above the threshold of 0.7 hence the constructs were considered to be at the acceptable level, thus, there was no need to delete any item.

\subsection{Sustainable Growth of SMEs (SGSMEs)}

Table 41. Reliability Statistics

\begin{tabular}{lr}
\hline Cronbach's Alpha & N of Items \\
\hline .780 & 6 \\
\hline
\end{tabular}


Table 42. Item-Total Statistics

\begin{tabular}{llcccc}
\hline & $\begin{array}{l}\text { Scale Mean } \\
\text { Deleted }\end{array}$ & $\begin{array}{c}\text { if } \\
\text { Deleted }\end{array}$ & $\begin{array}{c}\text { ItemScale Variance if } \\
\text { Dorrelation }\end{array}$ & $\begin{array}{c}\text { Item-TotalCronbach's Alpha } \\
\text { Item Deleted }\end{array}$ \\
\hline GMSMEs1 & 15.97 & 17.221 & .558 & .739 \\
GMSMEs2 & 16.13 & 17.549 & .430 & .776 \\
GMSMEs3 & 15.89 & 18.341 & .493 & .756 \\
GMSMEs4 & 15.90 & 19.061 & .433 & .769 \\
GMSMEs5 & 16.01 & 16.576 & .630 & .721 \\
GMSMEs6 & 15.95 & 16.795 & .644 & .718 \\
\hline
\end{tabular}

The construct reliability of the six items used to ascertain the sustainable growth of the SMEs also carried an alpha value of 0.780 which was above the 0.7 threshold, thus the constructs were considered to be at the acceptable level (Diamantopoulos, Sarstedt, Fuchs, Wilczynski \& Kaiser, 2012; Cheah, Sarstedt, Ringle, Ramayah \& Ting, 2018). As a result, there was no need to delete any item.

\section{Conclusion}

As has been described and analysed above, the construct reliability of all the items designed in the questionnaire were thoroughly assessed using the Cronbach alpha value. The results indicated that all the constructs had a high alpha value of above 0.7 , suggesting that all the items used in the questionnaire should be maintained. Based on the present business status of the SMEs and the enterprise which the respondents were attached to, it appears that most of the enterprises belonged to the medium range enterprises. The demographic information of the enterprises were drawn based on: the sub-sector, the number of full-time employees hired, the nature of business of the enterprise or business unit/legal status, and the enterprise's basic assets (excluding land and buildings). The demographics of the respondents were also generated based on: gender, age, highest academic qualification, responsibilities, years of service, and the location/area of the respondents. All of these information may affect the outcomes of the sustainable growth of the SMEs in Nigeria. The respondents who were inexperienced, and with less than a year of working experience are likely to face considerable challenges when dealing with the activities of the enterprise they belong to.

This pilot study was conducted based on the objective of assessing the viability, length of time, cost, and adverse effects of using the survey questionnaire for the main study. This pilot study also helped to enhance the design and construction of items used in the survey questionnaire as it was pre-tested and reviewed by four experts so that there would be no obstacle faced during its actual implementation in the main study.

\section{References}

Al-Ansari, Y. D. Y. (2014). 'Innovation practices as a path to business growth performance: A study of small and medium sized firms in the emerging UAE market'. PhD thesis, Southern Cross University, Lismore, NSW. Retrieved from https://epubs.scu.edu.au/cgi/viewcontent.cgi?referer=https://scholar.google.com/\&httpsredir $=1 \&$ article $=1363 \&$ context $=$ theses

Arora, L., Kumar, S., \& Thapar, M. L. (2018). The anatomy of sustainable growth rate of Indian manufacturing firms. Global Business Review, 19(4), 1050-1071. https://doi.org/10.1177/0972150918773002

Awang, Z. (2015). SEM made simple: A gentle approach to learning structural equation modelling. Bandar Baru Bangi: MPWS Rich Resources.

Bento, S., Gaultney, W., \& Dahlquist, L. (2020). An exploratory factor analysis of the procedural coping questionnaire. Children's Health Care, 49(1), 55-68. https://doi.org/10.1080/02739615.2018.1558058

Blair, J., \& Conrad, F. G. (2011). Sample size for cognitive interview pretesting. Public Opinion Quarterly, 75(4). 636-658. https://doi.org/10.1093/poq/nfr035

Cheah, J. H., Sarstedt, M., Ringle, C. M., Ramayah, T., \& Ting, H. (2018). Convergent validity assessment of formatively measured constructs in PLS-SEM. International Journal of Contemporary Hospitality Management, 30(11), 3192-3210. https://doi.org/10.1108/JJCHM-10-2017-0649.

Chen, Y. S., Lin, M. J., \& Chang, C. H. (2009). The positive effects of relationship learning and absorptive capacity on innovation performance and competitive advantage in industrial markets. Industrial Marketing Management, 38(2), 152-158. https://doi.org/10.1016/j.indmarman.2008.12.003.

Cheng, C. C., \& Huizingh, E. K. (2014). When is open innovation beneficial? The role of strategic orientation. 
Journal of product innovation management, 31(6), 1235-1253. https://doi.org/10.1111/jpim.12148

Collins, D. (2003). Pretesting survey instruments: An overview of cognitive methods. Quality of Life Research, 12, 229-238. https://doi.org/10.1023/A:1023254226592

Cooper, D. R., \& Schindler, P. S. (2011). Business Research Methods (11th ed.). New York: McGraw-Hill.

Diamantopoulos, A., Sarstedt, M., Fuchs, C., Wilczynski, P., \& Kaiser, S. (2012). Guidelines for choosing between multi-item and single-item scales for construct measurement: A predictive validity perspective. Journal of the Academy of Marketing Science, 40(3), 434-449. https://doi.org/10.1007/s11747-011-0300-3

Eggers, F., Kraus, S., Hughes, M., Laraway, S., \& Snycerski, S. (2013b). Implications of customer and entrepreneurial orientations for SME growth. Management Decision, 51(3), 524-546. https://doi.org/10.1108/00251741311309643

Eggers, F., O’Dwyer, M., Kraus, S., Vallaster, C., \& Güldenberg, S. (2013a). The impact of brand authenticity on brand trust and SME growth: A CEO perspective. Journal of World Business, 48(3), 340-348. https://doi.org/10.1016/j.jwb.2012.07.018

Garrett, R. P., \& Neubaum, D. O. (2013). Top management support and initial strategic assets: A dependency model for internal corporate venture performance. Journal Production Innovation Management, 30(5), 896915. https://doi.org/10.1111/jpim.12036.

Gatignon, H., \& Xuereb, J. M. (1997). Strategic orientation of the firm and new product performance. Journal of Marketing Research, 34(1) 77-90. https://doi.org/10.1177/002224379703400107

Gorsuch, R. L. (1983). Factor analysis (2nd Ed.). Hillsdale, NJ: Erlbaum.

Hadi, N. U., Abdullah, N., \& Sentosa, I. (2016). An easy approach to exploratory factor analysis: Marketing perspective. Journal of Educational and Social Research, 6(1), 215. https://doi.org/10.5901/jesr.2016.v6n1p215

Hair, J. F., Black, W. C., Babin, B. J., \& Anderson, R. E. (2010). Multivariate data analysis (7th ed.). Englewood Cliffs: Prentice Hall. https://doi.org/10.1016/j.jmva.2009.12.014

Halac, S. D. (2015). Multidimensional construct of technology orientation. Procedia-Social and Behavioural Sciences, 195(3), 1057-1065. https://doi.org/10.1016/j.sbspro.2015.06.149.

Hill, R. (1998). What sample size is "enough" in internet survey research? Interpersonal computing and technology: An Electronic Journal for the 21st Century, 6(3-4), 1-10.

Hoque, A. S. M., Awang, Z., Jusoff, K., Salleh, F., \& Muda, H. (2017). Social business efficiency: Instrument development and validation procedure using structural equation modelling. International Business Management, 11(1), 222-231. https://doi.org/10.3758/s13428-016-0816-z

Isaac, S., \& Michael, W. B. (1995). Handbook in research and evaluation. San Diego, CA: Educational and Industrial Testing Services.

Jung, S., \& Lee, S. (2011). Exploratory factor analysis for small samples. Behaviour Research Method, 43, 701709. https://doi.org/10.3758/s13428-011-0077-9

Kelley, K., Clark, B., Brown, V. \& Sitzia, J. (2003). Good practice in the conduct and reporting of survey research. International Journal for Quality in health care, 15(3), 261-266. https://doi.org/10.1093/intqhe/mzg031

Kline, P. (1994). An easy guide to factor analysis. New York: Routledge.

Lo, C. M., Wang, C. Y., Wah, J. R. C., \& Ramayah, T. (2016). The critical success factors for organisational performance of SMEs in Malaysia: A partial least squares approach Review of Business Management São Paulo, 18(61), 370-391. https://doi.org/10.7819/rbgn.v18i61.3058.

Memon, M. A., Ting, H., Ramayah, T., Chuah, F. \& Cheah, J. H. (2017). A review of the methodological misconceptions and guidelines related to the application of structural equation modeling: A Malaysian scenario. Journal of Applied Structural Equation Modelling, 1(1), 1-13.

Paswan, A. K., \& Wittmann, C. M. (2009). Knowledge management and franchise systems. Industrial Marketing Management, 38(2), 173-180. https://doi.org/10.1016/j.indmarman.2008.12.005

Pearson, R. H., \& Mundform, D. J. (2010). Recommended sample size for conducting exploratory factor analysis on dichotomous data. Journal of Modern Applied Statistical Methods, 9(2), 359-368. 
https://doi.org/10.22237/jmasm/1288584240

Pucihar, A., Lenart, G., Kljajić Borštnar, M., Vidmar, D., \& Marolt, M. (2019). Drivers and outcomes of business model innovation-micro, small and medium-sized enterprises perspective. Sustainability, 11(2), 344-17. https://doi.org/10.3390/su11020344

Sang, L. T., Mail, R., Karim, M. R. A., Ulum, Z. K. A. B., Mifli, M., \& Lajuni, N. (2017). Pretesting and piloting the research instrument to examine the central roles of risk perception and attitude towards financial investment behavioral intention among Malaysians. Journal of the Asian Academy of Applied Business, 4, 97-108.

Saunders, M., Lewis, P., \& Thornhill, A. (2007). Research methods for business, 4th ed., Pearson Education, Harlow.

Saunders, M., Lewis, P., \& Thornhill, A. (2012). Research methods for business students. Pearson Education Ltd., Harlow.

Sekaran, U. (2003). Research methods for business: A skill building approach (4th ed.). United State of America: John Willey and Sons, Inc.

Sheng, M. L., Chang, S., Teo, T. \& Lin, Y. (2013). Knowledge barriers, knowledge transfer, and innovation competitive advantage in healthcare settings. Management Decision, 51(3), $461-478$. https://doi.org/10.1108/0025174131130960

Tang, T. L. P., Kim, J. K., \& O’Donald, D. A. (2000). Perception of Japanese organisational culture: Employees in non-unionized Japanese owned and unionized US-owned automobile plant. Journal of Managerial Psychology, 15(6), 535-559. https://doi.org/10.1108/02683940010373383

\section{Copyrights}

Copyright for this article is retained by the author(s), with first publication rights granted to the journal.

This is an open-access article distributed under the terms and conditions of the Creative Commons Attribution license (http://creativecommons.org/licenses/by/4.0/). 